\title{
Age-related Changes in the Cellular Level of Amylase and Protein Synthesis in the Rat Parotid Gland
}

\author{
SUN-KEE KIM
}

Research Service, V.A. Medical Center, Ann Arbor, Michigan 48105 and Department of Anatomy, The University of Michigan Medical School, Ann Arbor, Michigan 48109

Age-related changes in the cellular content of secretory proteins and protein synthesis were studied in parotid glands of rats of various ages. The secretory protein content (determined by measuring the level of $\alpha$-amylase activity) and the synthesis of proteins lassayed by the rate of incorporation of ${ }^{3}$ H-leucine into acid-insoluble proteins) decline with increasing age. Morphological and radioautographic studies of the gland indicate that the decline in protein synthesis is due to the reduction in the ability of secretory cells to synthesize proteins.

J Dent Res 60(3):738-747, March 1981

\section{Introduction.}

Previous studies have indicated that agerelated changes occur in the function of salivary glands in humans. The rate of flow is reduced in elderly persons, ${ }^{1,2}$ and basal (fasting), as well as stimulated (chewing), secretion of saliva is decreased considerably in older persons ( 90 years old) compared to younger persons (12-60 years old). Furthermore, the enzyme content of the saliva is reduced; a reduction in the content of amylase $1,3,4$ in mixed saliva has been reported in elderly persons.

The changes mentioned above, especially those involving the reduction in the level of salivary enzymes, suggest that the synthesis of secretory proteins in salivary glands declines with increasing age. The reduction in protein synthesis with aging is a phenomenon observed widely in many different types of tissues. A decline in protein synthesis has been demonstrated in prostate ${ }^{5}$ liver, ${ }^{6-9}$ brain, ${ }^{10-12}$ muscle, ${ }^{13,14}$ testis, ${ }^{15}$

Received for publication February 4, 1980 Accepted for publication May 8, 1980

This study was supported in part by the Veterans Administration and Grant AG 00944 from the National Institute on Aging, National Institutes of Health. and lens. ${ }^{16}$ We have also reported previously that the synthesis of proteins declines with aging in parotid salivary glands. ${ }^{17-19}$

To determine whether the cellular content of secretory proteins decreases with the reduction in protein synthesis in salivary glands, the differences in the level of $\alpha$ amylase activity and the incorporation of ${ }^{3} \mathrm{H}$-leucine into acid-insoluble proteins have been compared in parotid glands of rats of varying ages. The rat parotid gland provides an excellent system for this kind of study since the gland consists primarily of one type of secretory cell which produces a purely proteinaceous secretion consisting largely of $\alpha$-amylase. This enzyme is fairly stable and can be assayed readily for its activity. The results from this study indicate that the cellular level of secretory proteins, as well as the ability of acinar cells to synthesize proteins, declines with increasing age in parotid glands of the rat.

\section{Materials and methods.}

Animals. -- Male Sprague-Dawley rats two, 12, 18, 24, and 30 mo of age were used. $\dagger$ All rats were of the same strain of caesarean-derived rats, except that older ones ( 12 mo and older) came from the aging colony maintained by the N.I.A. at the same breeding laboratory. All rats were housed in an isolator upon arrival and allowed to acclimate for at least three $d$ before experiments were begun. Food was removed from these rats approximately $17-18 \mathrm{~h}$ before the experiment, but they were allowed access to drinking water. All rats were sacrificed by cervical dislocation between 8 and 9 a.m. on the day of the experiments. The parotid glands were removed from the rats

†Charles River Breeding Laboratories, Wilmington, MA 
and placed in a dish of ice-cold phosphatebuffered saline (PBS) for assays of $\alpha$-amylase activity and in Minimum Essential Medium $(\mathrm{MEM})^{\S}$ for ${ }^{3} \mathrm{H}$-leucine incorporation studies. After removing the connective tissue, nerves, and large ducts in the central region, the glands were sliced with the StadieRiggs tissue slicer for incubation with the radioactive amino acid. Small pieces of the gland from old rats were prepared for pathological screening.

Assays of a-amylase activity and determinations of DNA content. - The glandular $\alpha$-amylase was extracted by an extensive homogenization of the tissue in PBS $(\mathrm{pH}$ $6.9,3.0 \mathrm{ml} / 0.1 \mathrm{~g}$ wet weight of the gland). A small amount of the homogenate was removed and centrifuged at $25,000 \mathrm{~g}$ for ten min; the supernatant was used to assay for its $\alpha$-amylase activity following appropriate dilutions. The $\alpha$-amylase activity was assayed by using the Amylochrome method, which is a colorimetric procedure of measuring the amount of dye released from the Cibachrome Blue $F_{3}$ GA-amylose complex when the $1-4$ bonds of the amylose are broken by the action of $\alpha$-amylase. This assay method was used instead of Bernfeld's technique 20 because of its high sensitivity and consistency. When tested by using hog pancreas amylase, ${ }^{\circ} 1050$ dye units were comparable to 1 unit of $\alpha$-amylase activity. This activity produces $1 \mathrm{mg}$ maltose from starch in three min at $37^{\circ} \mathrm{C}$.

The remaining homogenate was precipitated with perchloric acid (PCA, final concentration of $0.3 \mathrm{~N}$ ) and fractionated as described by Hinrichs et al. ${ }^{21}$ DNA was extracted with hot $\left(70^{\circ} \mathrm{C}\right) 0.5 \mathrm{~N}$ PCA from the resulting pellet, and the amount of it was determined according to the diphenylamine method of Burton, 22 using calf thymus $\mathrm{DNA}^{\circ}$ as the standard.

${ }^{3}$ H-leucine-incorporation studies. - Tissue slices were collected in a petri dish containing ice-cold MEM, which had been gassed with $95 \% \mathrm{O}_{2}$ and $5 \% \mathrm{CO}_{2}$, and divided into groups for incubation. Each group was placed in a $25-\mathrm{ml}$ Erlenmeyer flask, containing $5 \mathrm{ml}$ of MEM without leucine. Three

\footnotetext{
§Grand Island Biological Co., Grand Island, NY

$\ddagger$ Roche Diagnostics, Nutley, NJ

oSigma, St. Louis, MO
}

$\mu \mathrm{Ci} / \mathrm{ml}$ of $\mathrm{L}-\left[4,5,{ }^{3} \mathrm{H}(\mathrm{N})\right]$-leucine (sp. act. 47-52 $\mathrm{Ci} / \mathrm{mmol}$ ) were added and supplemented with ${ }^{1} \mathrm{H}$-leucine to a total concentration of $0.1 \mathrm{mM}$. Flasks containing tissue slices and medium were continuously gassed and kept on ice for ten $\min$ for equilibration. After this, flasks were transferred to a water bath maintained at $37^{\circ} \mathrm{C}$ and agitated at about $90 \mathrm{cycles} / \mathrm{min}$ while maintaining the $95 \% \mathrm{O}_{2}$ and $5 \% \mathrm{CO}_{2}$ atmosphere. At the end of the incubation, flasks were put on ice, and tissues were removed from the medium by filtering through miracloth. Tissues were further rinsed with cold PBS and homogenized. A known amount of the homogenate was removed for the determination of total radioactivity. The remaining homogenate was precipitated with cold PCA (final concentration, $0.3 \mathrm{~N}$ ) and fractionated to obtain PCA-insoluble protein and extract DNA, as described in the previous section. The supernatant was used to determine the ${ }^{3} \mathrm{H}$-leucine available in the PCA-soluble pool. The PCA-insoluble pellet was dissolved in NCS tissue solubilizer" following the extraction of DNA. The amount of DNA was determined according to Burton, ${ }^{22}$ as described previously. Radioactivity in acidsoluble fractions and in dissolved pellets was counted in a Packard Scintillation Spectrometer. Counting rates were corrected for quenching and background with an external standard. Total leucine incorporated into proteins was calculated from the total radioactivity and the specific activity of ${ }^{3} \mathrm{H}$-leucine in the medium.

Light and electron microscopy. - The glands were fixed by perfusing the animal's heart with a mixture of $1 \%$ paraformaldehyde and $1.5 \%$ glutaraldehyde buffered with $0.1 \mathrm{M}$ sodium cacodylate to $\mathrm{pH} 7.4$. Glands were removed, sliced into smaller pieces, and further fixed in the same mixture for an additional hour. Tissues were post-fixed in $1 \%$ solution of $\mathrm{OsO}_{4}$ and prepared for microscopy as described previously. ${ }^{23}$

For light microscopy, $1 \mu \mathrm{m}$-thick sections were cut and stained with $1 \%$ toluidine blue for viewing. For electron microscopy, silver to gold sections $(700-900 \AA)$, cut on a Porter-Blum MTIIB microtome with a diamond knife, were stained with uranyl

I New England Nuclear, Boston, MA

"Amersham, Arlington Heights, IL 
acetate followed by lead citrate for viewing and photographing in a Hitachi $11 \mathrm{C}$ electron microscope operated at $75 \mathrm{KV}$.

For radioautography, two each of twomonth- and 24-month-old rats were injected with $1 \mu \mathrm{Ci} / \mathrm{g}$ (body weight) of $\mathrm{L}-^{3} \mathrm{H}$-leucine (sp. act. 47-52 $\mathrm{Ci} / \mathrm{mmol}$ ). Parotid glands were removed from these rats $90 \mathrm{~min}$ after the injection, sliced, and fixed in $10 \%$ formaldehyde in $0.175 \mathrm{M}$ potassium phosphate buffer ( $\mathrm{pH}$ 7.2). The fixative was changed several times and further fixed overnight in the refrigerator. The tissue slices were dehydrated and embedded in Epon. ${ }^{23}$ Sections of $1 \mu$ thick were cut and placed on microscope slides. Slides were dip-coated with NTB 2 emulsion \# diluted with distilled water in a darkroom maintained at $21^{\circ} \mathrm{C}$ and $70 \%$ relative humidity. After five wk of exposure in the refrigerator, slides were developed in D19\# diluted $1: 2$ with water; they were then fixed, rinsed, and stained briefly with $1 \%$ toluidine blue.

\section{Results.}

Comparisons of the biochemical data obtained from the studies of the different age groups have been made based on the DNA content of the gland. The wet weight index was not used to avoid fluctuations in the glandular weight due to possible changes with age in the amount of non-parenchymal tissues, such as fibrous connective tissue and fat. However, the data based on the weight of the gland are included for purposes of

\#Eastman Kodak Co., Rochester, NY comparison with those based on the DNA content.

Levels of $\alpha$-amylase activity. - The $\alpha$ amylase activity is highest in the glands of 12-month-old rats, and it is reduced significantly in older $(18,24$, and $30 \mathrm{mo})$ rats (Table 1). It appears that the glandular level of $\alpha$-amylase activity does not change significantly with age after it reaches the low level at $18 \mathrm{mo}$. The level of the enzyme activity in young (two mo) rats is intermediate between that of the 12-month-old and older rats and appears to increase to a higher level by $12 \mathrm{mo}$. When the values for the enzyme activity are expressed as per $\mathrm{mg}$ tissue, the general trend of changing levels of $\alpha$-amylase activity with age is similar to that of the levels based on mg DNA (Table 1). There is no significant difference in the amount of DNA/mg tissue among the age groups (Table 2).

Microscopic structure of the gland. The histological appearance of the gland remains similar up to 24 mo (Figs. 1 and 2), with the exception of the increase in the amount of fatty tissues with age. There are no drastic changes in the proportions of parenchymal to stromal tissues or secretory to non-secretory cells. The acinar cells of the gland in old rats (Fig. 2) are generally filled with secretory granules as is the case in the gland of young rats (Fig. 1). These acinar cells are arranged around the secretory lumen which appears to be somewhat dilated in old rats (Fig. 2).

Fatty tissue is not detected in the gland of two-month-old rats, but is present at 12 mo and considerably increases in older rats.

TABLE 1

AGE-RELATED DIFFERENCES IN $\alpha$-AMYLASE ACTIVITY IN THE RAT PAROTID GLAND

\begin{tabular}{cccc}
\hline & $\begin{array}{c}\text { Number } \\
\text { of } \\
\text { Rats }\end{array}$ & $\begin{array}{c}\text { Dye Units } \\
\text { mg tissue } \pm \text { S.E. } \\
(\mathrm{x} \mathrm{10})\end{array}$ & $\begin{array}{c}\text { Dye Units } \\
\text { mg DNA } \pm \text { S.E. } \\
\left(\mathrm{x} \mathrm{10^{6 }}\right)\end{array}$ \\
\hline 2 & 4 & $100.1 \pm 3.1 \mathrm{a}, \mathrm{b}, \mathrm{c}, \mathrm{d}$ & $25.2 \pm 1.3^{\mathrm{b}, \mathrm{c}}$ \\
12 & 5 & $116.8 \pm 4.6 \mathrm{~b}, \mathrm{c}, \mathrm{d}$ & $30.2 \pm 1.9 \mathrm{~b}, \mathrm{c}, \mathrm{d}$ \\
18 & 5 & $82.1 \pm 4.8$ & $20.4 \pm 1.2$ \\
30 & 4 & $69.5 \pm 3.2$ & $19.9 \pm 1.1$ \\
\hline
\end{tabular}

a Value differs significantly from the 12 -month value $(P \leq 0.05)$

bValue differs significantly from the 18 -month value $(P \leq 0.05)$.

cValue differs significantly from the 24 -month value $(\mathrm{P} \leq 0.05)$.

dValue differs significantly from the 30 -month value $(P \leq 0.05)$. 
TABLE 2

THE INCORPORATION OF LEUCINE INTO ACID-INSOLUBLE PROTEINS BY THE RAT PAROTID GLAND

\begin{tabular}{cccc}
\hline Age (months) & $\begin{array}{c}\text { Number } \\
\text { of } \\
\text { Rats }\end{array}$ & $\begin{array}{c}\text { nanomoles/ } \\
\text { mg DNA } \pm \text { S.E. } \\
\text { h }\end{array}$ & $\begin{array}{c}\mu \mathrm{g} \text { DNA } \\
\text { mg tissue } \\
\pm \text { S.E. }\end{array}$ \\
\hline 2 & 4 & $138.43 \pm 5.45^{\mathrm{a}, \mathrm{b}, \mathrm{c}, \mathrm{d}}$ & $4.05 \pm 0.14$ \\
12 & 5 & $109.77 \pm 6.88^{\mathrm{c}, \mathrm{d}}$ & $3.73 \pm 0.11$ \\
18 & 8 & $97.77 \pm 4.68^{\mathrm{c}, \mathrm{d}}$ & $3.82 \pm 0.17$ \\
24 & 4 & $71.62 \pm 4.13$ & $3.58 \pm 0.21$ \\
30 & 3 & $58.08 \pm 5.61$ & $3.73 \pm 0.10$ \\
\hline
\end{tabular}

a Value differs significantly from the 12 -month value $(P \leq 0.05)$.

bValue differs significantly from the 18 -month value $(\mathrm{P} \leq 0.05)$.

cValue differs significantly from the 24 -month value $(\mathrm{P} \leq 0.05)$.

dValue differs significantly from the 30 -month value $(P \leq 0.05)$.

Fat globules are present mostly at the periphery of the secretory lobules or in the connective tissue capsules around the lobules in the gland of rats up to $24 \mathrm{mo}$. However, fat is present in many secretory lobules and even within the acinar and ductal cells of the gland in 30-month-old rats (Fig. 3). Some secretory cells in these old rats are filled with fat globules instead of secretory granules.

When viewed in the electron microscope, secretory acinar cells and some ductal cells in the gland of 12-month-old and older rats reveal lipofuscin granules (Fig. 4). The number of these granules seems to increase with age. In addition, many secretory cells in 30-month-old rats contain some lipid granules which are mainly found at the basal portion of the cell (Fig. 4). Other than the presence of these granules, there is no significant difference in the fine structure of organelles which can be detected without the quantitative analysis.

Levels of ${ }^{3}$ H-leucine incorporation into tissue proteins. - Gland slices from different age groups were routinely incubated for $30 \mathrm{~min}$ in the medium containing ${ }^{3} \mathrm{H}$-leucine, because the label is incorporated into PCAinsoluble proteins at a constant rate for up to four $h$ in all age groups (unpublished observation). The incorporation values among age groups were compared based on nanomoles leucine incorporated nmoles per mg DNA $^{-1}$ per $\mathrm{h}^{-1}$.

The level of incorporation of leucine into PCA-insoluble proteins is highest in the glands of two-month-old rats, and it decreases progressively with increasing age by $21,29,49$, and $58 \%$ of the two-month level in $12,18,24$, and 30 -month-old rats, respectively (Table 2 ). On the other hand, the amount of leucine incorporated into the acid-soluble fractions of the gland does not change significantly with age. The amount of leucine incorporated into the acid soluble fraction at two and $24 \mathrm{mo}$ is $0.14 \pm 0.02$ nmoles per mg DNA ${ }^{-1}$ per $h^{-1}$, while the same value at $24 \mathrm{mo}$ is $0.12 \pm 0.02$ nmoles per mg DNA ${ }^{-1}$ per $\mathrm{h}^{-1}$.

The label appears to be incorporated into all secretory cells of the gland. In radioautographs of the gland prepared from the rats injected with ${ }^{3} \mathrm{H}$-leucine, grains are present in all cells of the gland in both young and old rats including the secretory acinar and ductal cells (Fig. 5). However, the numbers of grains associated with the secretory acinar cells are clearly larger than those found over the ductal cells (Fig. 5).

\section{Discussion.}

The differences in the level of $\alpha$-amylase activity in parotid glands of the various age groups in this study suggest that the cellular content of secretory proteins declines with age. The amylase content seems to be reduced significantly between 12 and $18 \mathrm{mo}$ and appears to remain at about the same level up to $30 \mathrm{mo}$. This pattern of changes in the secretory protein content does not parallel that of the changes in the cellular protein synthesis, indicated by the agerelated differences in the ${ }^{3} \mathrm{H}$-leucine incorporation into acid-insoluble proteins of the gland. However, it is not unreasonable to expect to find this kind of discrepancy since the cellular content of secretory proteins is 

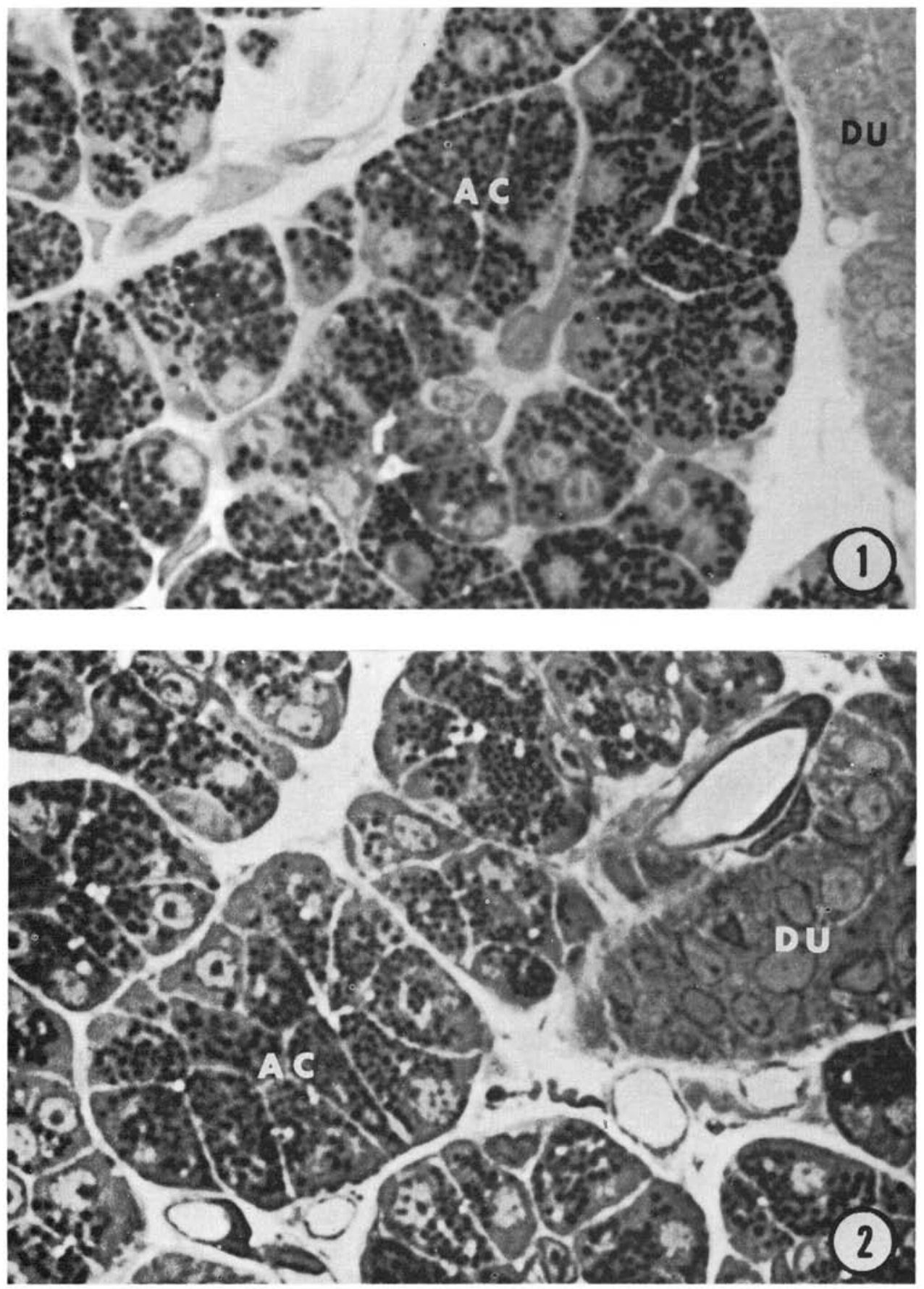

Figs. 1 and $2-$ Light micrographs of $1 \mu$ Epon sections showing the parotid gland from two- (Fig. 1) and 24- (Fig. 2) month-old rats. There is no obvious difference in the histological appearance of the secretory acini (AC) or ducts (DU) in the glands of these two age groups with the exception of somewhat dilated acinar lumens in the older rats. $(\mathrm{x} 1,000)$ 


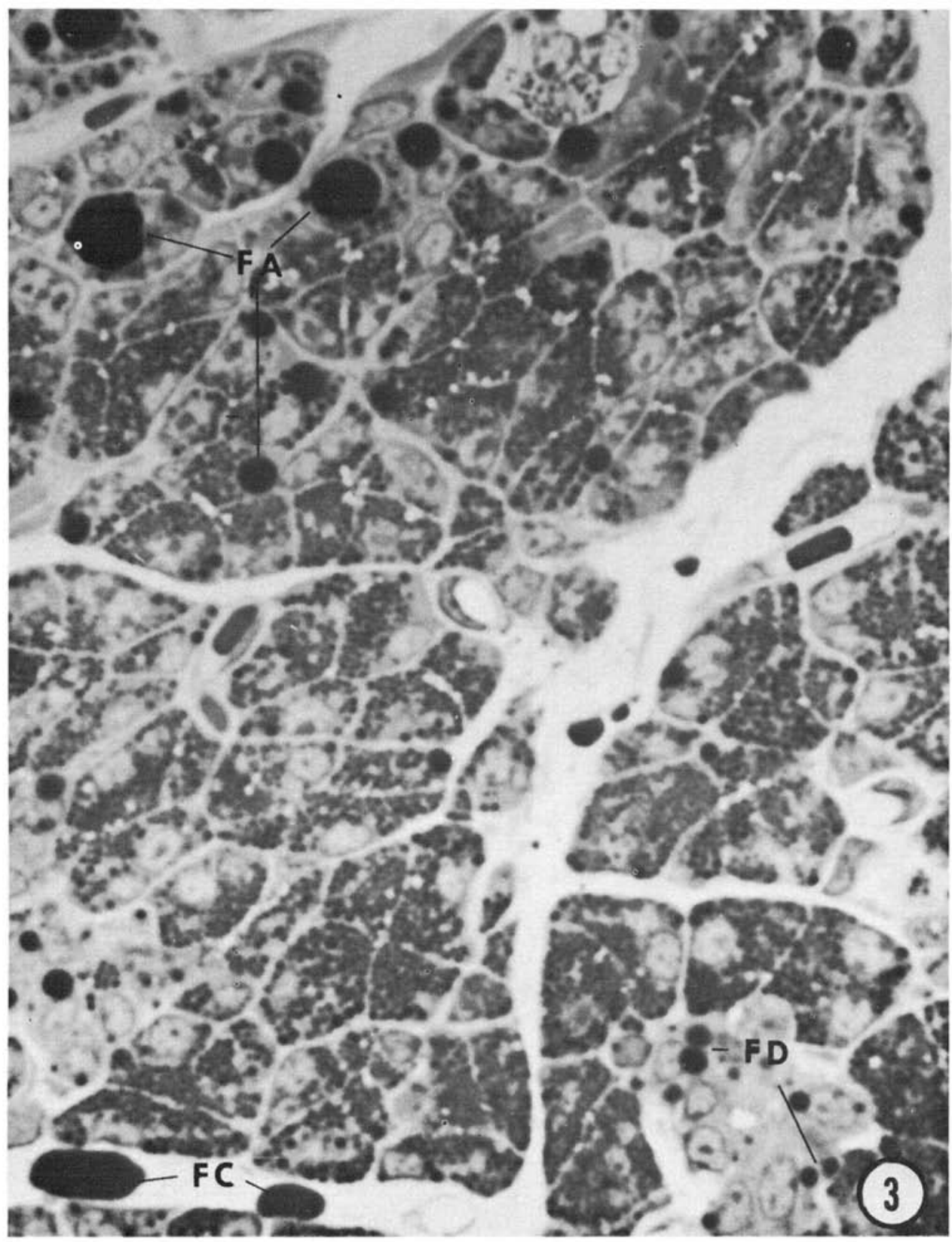

Fig. 3 - Light micrograph of $1 \mu$ Epon section showing the parotid gland from a 30-month-old rat. Fat globules are present in the connective tissue (FC) around the secretory lobules, as well as in the acinar (FA) and ductal (FD) cells. Some of these fat globules (FA) are large and appear to fill most of the cellular space. $(\mathrm{x} 1,000)$ 


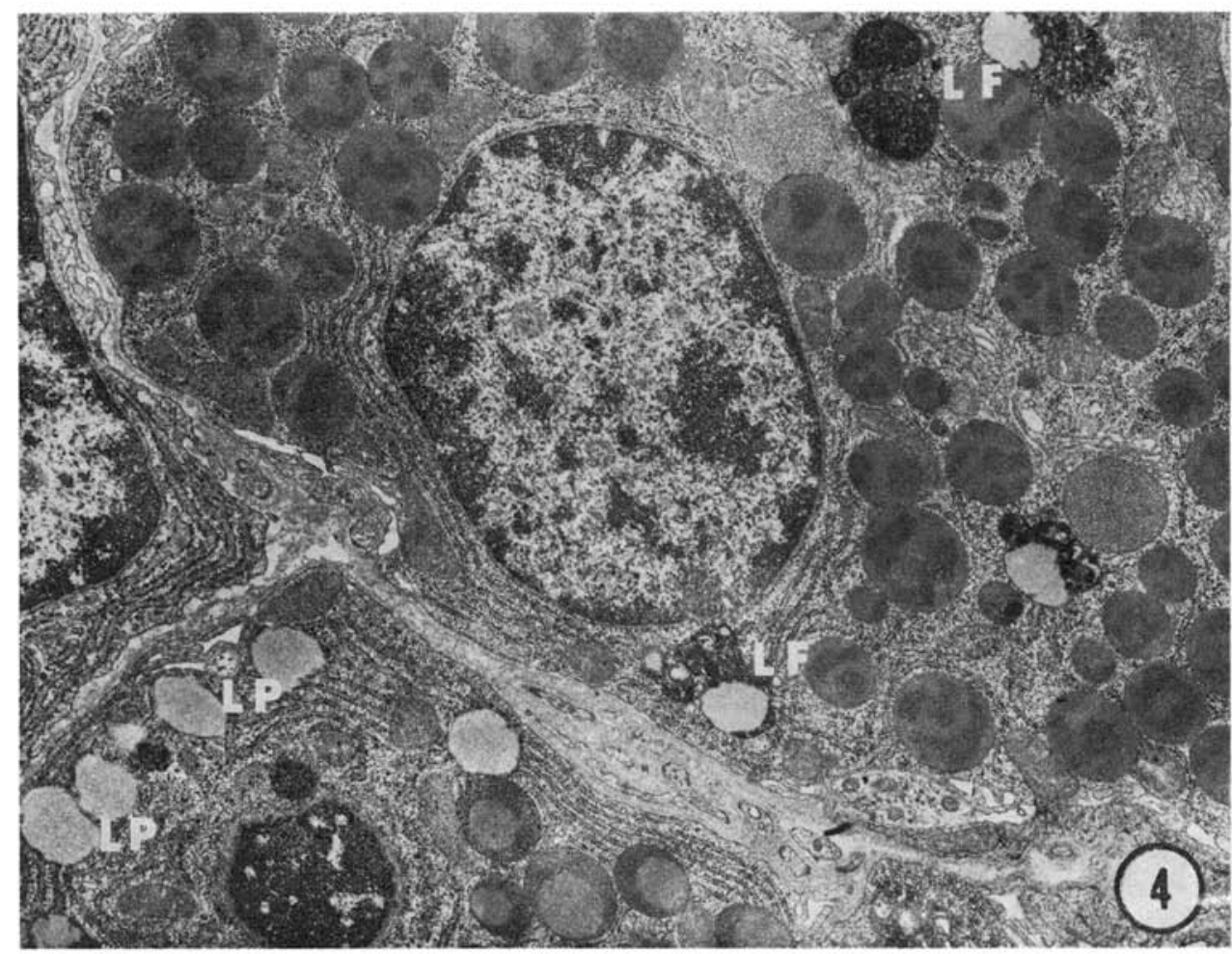

Fig. 4 - Electron micrograph showing a portion of the gland from a 30-month-old rat. The secretory granules of old rats are often heterogeneous in appearance. A large number of lipofuscin granules (LF) are scattered in the cytoplasm throughout the cell. In addition, many acinar cells contain lipid droplets (LP), which are frequently concentrated in the basal cytoplasm near the nucleus. No further unusual appearance is detectable in relation to other cellular organelles. $(x 15,600)$

dependent on factors other than the level of cellular protein synthesis. It is related to the level of masticatory activity of the ani$\mathrm{mal}^{24,25}$ and is influenced by the activity of the autonomic innervations to the gland. ${ }^{26,27}$ In fact, the rate of protein synthesis in the parotid gland increases to the highest level when the cells are almost completely depleted of $\alpha$-amylase, following stimulated secretion with isoproterenol. ${ }^{28}$ Nevertheless, it is likely that the cellular content of secretory proteins is affected by the changes in the level of protein synthesis.

The progressive reduction in the incorporation of ${ }^{3} \mathrm{H}$-leucine into acid-insoluble proteins of the gland indicates that cellular protein synthesis declines with aging. The results from our biochemical and morphological studies suggest that this decline is due to the changes in the ability of the secretory cells to synthesize proteins, rather than the changes in the number of cells or other factors, such as the cellular metabolic activity or the size of the amino acid pool. The size of the free-leucine pool appears to remain stable with aging, as the incorporation of the amino acid into the acid-soluble fraction does not vary significantly up to 24 mo. The cellular metabolic activity, as measured by the ability of the parotid gland slices to oxidize ${ }^{14} \mathrm{C}$-glucose to ${ }^{14} \mathrm{CO}_{2}$, does not decline between two and 24 mo. ${ }^{18,19}$

The presence of radioactive grains in all recognizable acinar cells of the gland in rats injected with ${ }^{3} \mathrm{H}$-leucine demonstrates that the reduced level of leucine incorporation is not due to the reduction in the number of cells capable of incorporating the amino acid. Furthermore, there are no significant changes in the proportion of secretory cells to ductal cells or parenchymal to stromal 


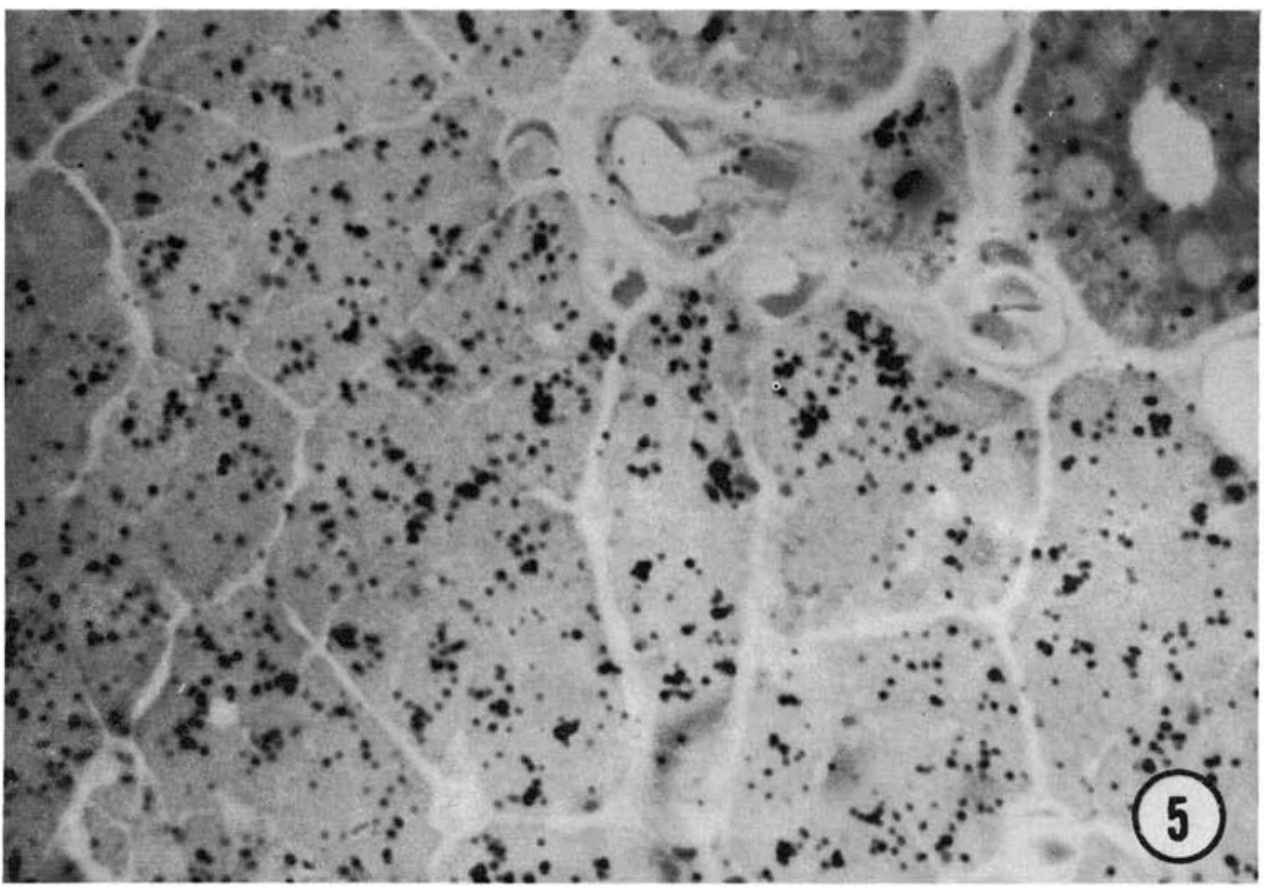

Fig. 5 - Light micrograph showing the radioautographic preparation of the gland from a 24-month-old rat which was injected with ${ }^{3} \mathrm{H}$-leucine $90 \mathrm{~min}$ prior to sacrifice. Radioautographic grains are present in almost all secretory acinar cells, indicating that all the acinar cells of the gland at this age incorporate the label (unstained preparation). (x1,000)

tissues up to 24 months. Although careful quantitations of the structural changes in the gland have not been done, it seems clear that there are no drastic morphological changes which parallel the reduction in protein synthesis $(\sim 50 \%)$ measured in the glands of 24-month-old rats.

However, there are noticeable differences in the structure of the gland in 30-month-old rats. Some of these structural changes are similar to those described previously by Andrew, ${ }^{29}$ and they include the increase in the amount of fatty and other connective tissue in the gland, as well as the appearance of lipid and lipofuscin granules in many secretory cells. Therefore, it is quite possible that these structural changes are at least partially responsible for the further reduction in the incorporation of leucine after 24 mo. However, structural changes do not fully explain the reduction in the amino acid incorporation up to $24 \mathrm{mo}$.

The decline in the ability of cells to synthesize protein is, by no means, a phenomenon unique to the rat parotid gland.
Many previous studies of in vitro amino acid incorporation have shown that tissues from older animals are less active in protein synthesis than those from younger animals. It remains uncertain as to what specific cellular changes are responsible for such a decline in protein synthesis. Many previous studies $^{6-8,10,14,30-34}$ have indicated that agerelated changes which occur in microsomes are among the causes for cellular changes in protein synthesis. Recently, it has been shown that the age-related decrease in the synthetic capacity of ribosomes is due to a reduction in the number of active ribosomes rather than a reduced efficiency in individual ribosomes. ${ }^{35}$ Whether or not such changes occur in ribosomes of the secretory cells in parotid glands of the rat remains to be investigated.

\section{Conclusions.}

This study has shown that the cellular level of $\alpha$-amylase activity and the incorporation of ${ }^{3} \mathrm{H}$-leucine into acid-insoluble 
proteins decline with age in parotid glands of the rat. In radioautographs of the gland from the rats which were injected with the labeled amino acid, grains are present in all secretory acinar cells. These results indicate that the ability of secretory cells to synthesize protein declines with increasing age.

\section{REFERENCES}

1. MEYER, J. and NECHELES, H.: Studies in Old Age. IV. The Clinical Significance of Salivary, Gastric, and Pancreatic Secretion in the Aged, $J$ Amer Med Assoc 115:2050$2053,1940$.

2. BERTRAM, U.: Xerostomia: Clinical Aspects, Pathology, and Pathogenesis, Acta Odont Scand 25(Suppl 49):1-126, 1967.

3. MEYER, J.; GOLDEN, J.S.; STEINER, N.; and NECHELES, H.: The Ptyalin Content of Human Saliva in Old Age, Am J Physiol 119: 600-602, 1937.

4. CHILLA, R.; NIEMANN, H.; ARGLEBE, C.; and DOMAGK, G.F.: Age-dependent Changes in the Alpha-isoamylase Pattern of Human and Rat Parotid Glands, ORL 36:372-382, 1974.

5. MAINWARING, W.I.P.: Changes in the Ribonucleic Acid Metabolism of Aging Mouse Tissues with Particular Reference to the Prostate Gland, Biochem J 110:79-86, 1968.

6. MAINWARING, W.I.P.: The Effect of Age on Protein Synthesis in Mouse Liver, Biochem $J$ 113:869-878, 1969.

7. HRACHOVEC, J.P.: Age Changes in Amino Acid Incorporation by Rat Liver Microsomes, Gerontologia 15:52-63, 1969.

8. KURTZ, D.I.: The Effect of Aging on in vitro Fidelity of Translation in Mouse Liver, Biochim Biophys Acta 407:479-484, 1975.

9. LAYMAN, D.K.; RICCA, G.A.; and RICHARDSON, A.: The Effect of Age on Protein Synthesis and Ribosome Aggregation to Messenger RNA in Rat Liver, Arch Biochem Biophys 173:246-254, 1976.

10. MURTHY, M.R.V.: Protein Synthesis in Growing Rat Tissues. II. Polyribosome Concentration of Brain and Liver as a Function of Age, Biochim Biophys Acta 119:599613,1966 .

11. JOHNSON, T.C.: Cell-free Protein Synthesis by Mouse Brain During Early Development, $J$ Neurochem 15:1189-1194, 1968.

12. JOHNSON, T.C. and BELYTSCHKO, G.: Alteration in Microsomal Protein Synthesis During Early Development of Mouse Brain, Proc Nat Acad Sic USA 62:844-851, 1969.

13. BREWER, C.B.; DAVIES, M.C.; and FLORINI, J.R.: Amino Acid Incorporation into Protein by Cell-free Preparations from Rat Skeletal Muscle. II. Preparation and Properties of Muscle Ribosomes and Polysomes, Biochem 3:1713-1719, 1964.

14. SRIVASTAVA, U.: Polyribosome Concentration of Mouse Skeletal Muscle as a Function of Age, Arch Biochem Biophys 130:129-139, 1969.

15. LIU, D.S.H.; EKSTROM, R.; SPICER, J.W.; and RICHARDSON, A.: Age-related Changes in Protein, RNA and DNA Content and Protein Synthesis in Rat Testes, Exp Gerontol 13:197-205, 1978.

16. KLETHI, J.: Incorporation of Glutamic Acid into Soluble Protein as a Function of Age, Invest Ophthal 15:430-433, 1976.

17. KIM, S.K.: Age-related Changes in Protein Synthesis in the Rat Parotid Gland, J Dent Res 58A:391,1979.

18. KIM, S.K.; WEINHOLD, P.A.; WAGNER, D.J.; and HAN, S.S.: Age-related Decline in Protein Synthesis in the Rat Parotid Gland, $J$ Cell Biol 83:439a, 1979.

19. KIM, S.K.; WEINHOLD, P.A.; HAN, S.S.; and WAGNER, D.J.: Age-related Decline in Protein Synthesis in the Rat Parotid Gland, Exp Gerontol 15:77-85, 1980.

20. BERNFELD, P.: Amylases $\alpha$ and $\beta$. In: Methods in Enzymology, Vol. I, Colowick, S.P. and Kaplan, N.O., Eds., New York: Academic Press, pp. 149-158, 1955.

21. HINRICHS, H.R.; PETERSEN, R.O.; and BASERGA, R.: Incorporation of Thymidine into DNA of Mouse Organs, Arch Path 78: 245-253, 1964.

22. BURTON, K.: A Study of the Conditions and Mechanism of the Diphenylamine Reaction for the Colorimetric Estimation of Deoxyribonucleic Acid, Biochem $J$ 62:315-323, 1956.

23. KIM, S.K.: The Cytochemical Localization of Adenylate Cyclase Activity in Mucous and Serous Cells of the Salivary Gland, $J$ Supramol Struct 4:185-197, 1976.

24. HALL, H.D. and SCHNEYER, C.A.: Salivary Gland Atrophy in Rat Induced by Liquid Diet, Proc Soc Exp Biol Med 117:789-793, 1964.

25. JOHNSON, D.A and SREEBNY, L.M.: Effect of Increased Mastication on the Secretory Process of the Rat Parotid Gland, Arch Oral Biol 18:1555-1558, 1973.

26. SCHNEYER, C.A. and HALL, H.D.: Autonomic Regulation of the Immature and Adult Rat Parotid Gland. In: Secretory Mechanisms of the Salivary Gland, Schneyer, L. and Schneyer, C., Eds., New York: Academic Press, 1967, pp. 155-177.

27. SCHNEYER, C.A.: Autonomic Regulation of Secretory Activity and Growth Response of Rat Parotid Gland. In: Secretory Mechanism of Exocrine Glands, Thorn, N.A. and Peterson, O.K., Eds., New York: Academic Press, 1974, pp. 42-55. 
28. LILLIE, J.H. and HAN, S.S.: Secretory Protein Synthesis in the Stimulated Rat Parotid Gland. Temporal Dissociation of the Maximal Response from Secretion, $J$ Cell Biol 59:708-721, 1973 .

29. ANDREW, W.: Age Changes in the Parotid Glands of Wistar Institute Rats with Special Reference to the Occurrence of Oncocytes in Senility, Am $J$ Anat 85:157-197, 1949.

30. BREWER, C.B. and FLORINI, J.R.: Amino Acid Incorporation into Protein by Cell-free Systems from Rat Skeletal Muscle. IV. Effects of Animal Age, Androgens, and Anabolic Agents on Activity of Muscle Ribosomes, Biochem 4:1544-1550, 1965.

31. BUETOW, D.E. and GANDHI, P.S.: Decreased Protein Synthesis by Microsomes Isolated from Senescent Rat Liver, Expt Gerontol $8: 243-249,1973$.
32. BRITTON, G.W. and SHERMAN, F.G.: Altered Regulation of Protein Synthesis During Aging as Determined by in vitro Ribosomal Assays, Exp Gerontol 10:67-77, 1975.

33. COMOLLI, R.: Polyamine Effects on ${ }^{14} \mathrm{C}$ leucine Transfer to Microsomal Protein in Rat Liver Cell-free System During Aging, Exp Gerontol 8:307-313, 1973.

34. COMOLLI, R.; DELPIANO, C. and SHUBERT, A.C.: Dependency on the Source of Supernatant Factors for Optimal 14C-polyphenylalanine Synthesis by High Salt-treated Liver Ribosomal Subunits in Rats of Different Ages, Exp Gerontol 11:5-10, 1976.

35. KURTZ, D.I.: A Decrease in the Number of Active Mouse Liver Ribosomes During Aging, Exp Gerontol 13:397-402, 1978.

International Symposium co-sponsored by the Tel Aviv University School of Dental Medicine and Alpha Omega International Fraternity-Toronto Chapter, entitled: "The Physiology of Occlusion and Its Clinical Application in Restorative Dentistry." The guest lecturer is Frank V. Celenza, D.D.S., M.S.C., Dept. of Prosthodontics, New York University, Boston University, U.S.A. Venue-Tel Aviv University Campus, April 29 and 30,1981 , and continuation May 11 and 12,1981. For further details contact: Dr. H.J. Levin, 2006 Bathurst St., Toronto, Ontario, Canada M5P 3L1, or Dr. H. Judes, School of Dental Medicine, Tel Aviv University, Ramat Aviv, Israel. 